\title{
Lazursky's Natural Experimentation as a Method of Personality Investigation in Brazil
}

\author{
Riviane B. Bravo \\ Universidade Federal de Minas Gerais, Belo Horizonte, Brazil \\ Centro Universitário Newton Paiva, Belo Horizonte, Brazil \\ Raquel M. de Assis \\ Universidade Federal de Minas Gerais, Belo Horizonte, Brazil
}

\begin{abstract}
The study of personality has always been presented in Psychology as a way to understand the individual's behavior and characteristics. Within such context, several theorists deepened their studies and used techniques to reveal the psychical world structure. By attempting to know the individual in their characterological profile, the psychologist and educator Helena Antipoff decided to revive her experience in the former Soviet Union by means of the observation models developed by the psychologist and psychiatrist Lazursky. When Antipoff arrived in Brazil in 1929, invited by the government to assist in the development of the educational reform in the period called New School, she started to spread Lazursky's work in the state of Minas Gerais. Antipoff used Lazursky's Natural Experimentation rather than intelligence tests in psychological evaluations as a method aimed at the characterization of personality through observations of the behaviors and routine under natural conditions. She researched about individuals by using systematized and standardized observations and experiments, whose results were analyzed methodologically in figure and tables, which helped her study the personality of both the students and teachers. The purpose of this paper is to show, based on primary source documents from Antipoff's publications between 1930's and 1950's, the study of the personality through the Natural Experimentation method as the main model for the beginning of her educational work in Brazil. The use of the method contributed to the new educational structure, once it consisted of investigating and evaluating the student according to his profile, that is, his personality.
\end{abstract}

Keywords: Natural Experimentation, personality, appropriation, education, character, characterological profile

\section{Introduction}

Alexandre Fedorovic Lazursky was a Russian psychologist and psychiatrist who developed research on human personality and individual differences (Campos, 2002; 2012). He focused his work on experimental research around 1896, along with his advisor Bekhterev. His study has enriched the classical Experimental Psychology (Korsakov, 1977). The Natural Experimentation method, based on Lazursky's researches and publications in Russia at the beginning of the 20th Century, was applied in several educational work contexts and also in different institutions by the psychologist and educator Helena Antipoff since her arrival in Brazil, in

Riviane Borghesi Bravo, doctor student at Universidade Federal de Minas Gerais; psychologist and professor at Centro Universitário Newton Paiva; researcher in History of Psychology.

Raquel Martins de Assis, Ph.D. professor at Universidade Federal de Minas Gerais; researcher in History of Psychology. 
the state of Minas Gerais, in the period between 1930 and 1950 (Campos, 2012).

At that time, the government of Minas Gerais implemented an educational reform based on the precepts of the New School and the scientific productions of psychology, biology, medicine, education, and so on (Borges, 2015; Campos, 2012). The main purpose of the method lay in identifying the characterological profile by means of real activities in a natural condition rather than the intelligence psychological testing that were considered artificial for evaluating and understanding the students enrolled in public schools.

However, the documental sources found for developing this study showed that not only the students went through this process called Natural Experimentation, but also the teachers who were preparing for the New School (Antipoff, Ottoni, \& Duarte, 1937; Antipoff \& Barbosa, 1943; Antipoff, 1945). We question and point out here the assumption that Antipoff may have incorporated Lazursky's method to a specific model of educational work that helped her investigate the personality as a way to evaluate the student's profile. Antipoff and Barbosa (1943) explained about the application of the Natural Experimentation in the context of Minas Gerais, Brazil, as follows:

We take the work here at the School not only as a way to teach students some jobs and techniques, which are useful in their lives, but also as a source through which we could get to know them better and as a powerful way to educate them both socially and morally. (para. 10)

Therefore, the present study aims to show Antipoff's appropriation by means of three applications of the Natural Experimentation method in several educational institutions in the state of Minas Gerais, in Brazil, with different goals. The documents for this study are primary sources published by Antipoff in education journals and meetings. She published the first document in the Infância Excepcional (Exceptional Childhood) of 1937 in collaboration with Francisca Ottoni and Cora Duarte during a research about the development of the activities at the Pestalozzi Institute. The second document took place at the Fazenda do Rosário (Rosario's Farm), aka "Chacrinha", in collaboration with Mrs. Yolanda Barbosa, found in one typescript of 1943, and later, at the Encontro Curso Pró Criança Excepcional (Pro Exceptional Childhood Meeting Course) of 1966. In the second document, there is the application of the method during the work of the under-aged boys in this boarding school supported by the Pestalozzi Society. Lastly, she published the third document in the Revista Brasileira de Estudos Pedagógicos (Brazilian Pedagogic Studies Journal) of 1945 and it reported the work about the characterological profiles of the teachers who were attending the psychology formation course at the Escola de Aperfeiçoamento (Improvement School).

\section{Helena Antipoff's Deeds in the State of Minas Gerais Context in Brazil}

Helena Wladimirna Antipoffwas born in Russia in 1892 and moved with her mother and sisters to Paris, France, in 1909. As she got to France, she enrolled herself at Sorbonne, where she considered studying medicine, as she attended the French philosopher Henri Bergson's seminaries held at the École Normale Supérieure and at the College de France. At the beginning of the 1910's, Antipoff participated in activities at the Psychology Laboratory at the University of Paris. She also went to England, which helped her improve her English and get experience as a French teacher and preceptor of the children at the housing she stayed in (Borges, 2015; Campos, 2012).

Due to the contact with the psychology science, she changed her study field and started to invest in her psychology education. It was at that time that Antipoff went to Alfred Binet's Laboratory and started 
collaborating with the initiatives and researches by the French doctor and psychologist Théodore Simon, known by elaborating, together with Alfred Binet, the Metric Scale of Intelligence. Later, she headed to Switzerland and integrated the team at the Jean-Jacques Rousseau Institute, becoming Édouard Claparède's assistant, collaborator and friend (Campos, 2012; Rafante \& Lopes, 2006). During the time she was in Geneva, the Russian educator was one of the teachers at the Maison des Petits, a school annex at the Jean-Jacques Rousseau Institute. At those institutions, Antipoff participated in the observations and experiments in educational psychology and pedology. Between 1921 and 1924, she returned to Russia where she started working in the triage, referring, and reeducation of orphan children from the World War I and the October Revolution in 1917, which enabled her to rethink the assessment of children through intelligent tests (Antipoff, 1992; Campos, 2002; Rafante \& Lopes, 2006). In Russia, the Natural Experimentation approach developed by the psychologist and psychiatrist Alexandre Fedorovic Lazursky, whose goal was to trace the child's personality profile by means of natural conditions, which enabled the observation of varied activities and the description of the behaviors, was being circulated (Campos, 2002).

In 1929, the state of Minas Gerais in Brazil invited Helena Antipoff to join the implementation team of the teaching reform known as Francisco Campos/Mário Casassanta Reform. One of the reforming Project investments was the creation of the Escola de Aperfeiçoamento de Professoras (Teachers' Improvement School) in the city of Belo Horizonte in 1929, which aimed at the formation of teachers and educational technicians from theories and scientific methods and through the parameters of the New School movement. The course offered at the Institution lasted two years and its syllabus comprised the disciplines of Pedology, Educational and Experimental Psychology, Teaching Methodology, Drawing and Modelling, School Legislation, Notions of Constitutional Law and Physical Education (Campos, 2012).

Helena Antipoff was in charge of the disciplines of Pedology and Experimental Psychology, besides implementing and directing the Psychology Laboratory at the Improvement School. In the School Programs, published in the Act 887 of June 30, 1937, there was the emphasis on the scientific investigation into the child, taking into account the individuality and the implication of mental functions in the school content acquisition process. This document cited Lazursky as an author of the material for the disciplines of Pedology and Experimental Psychology Applied to Education, and related to the "personality study", as follows:

The study of personality-constitution, temper, character, mental type. Factors influence over the formation of the personality: heredity, family environment, cultural-economical setting, education and self-learning. Some ethological classifications (Robot, Pavlov, Virenius, Lasoursky, Kretschmer, Spranger, Jung, Heymans). (Minas Gerais (Estado), 1937, p. 8)

The study of the personality, therefore, was one of the contents explored by Antipoff in the classes and activities at the Psychology Laboratory. The Program above cited Lazursky in the ethological classification field. Ethology is the scientific and objective study of animal behavior. In the disciplines of Psychology, the ethological classification used the natural method argued by Lazursky as it regarded the evaluation of personality by means of observation of the behavior under natural conditions.

\section{The Appropriation of Lazursky's Natural Experimentation Method for the Study of Personality}

Lazursky concentrated his work in psychology mainly at the Psychoneurology Institute in Saint Petersburg and his major advisor was the Russian neurologist Vladimir Mikhailovich Bekhterev, who was a neuroscientist 
that devoted himself to the studies about diagnosis and research in the neurology, psychology, morphology, physiology, and psychiatry areas. His major contributions to neurology lay in the descriptions of structures, signs and syndromes in physiology, besides having been one of the reflexology representatives, theory that gave basis to behaviorism in psychology, providing the development of the objective and suggestive psychology (Maranhão-filho, Maranhão, \& Engelhardt, 2015). From 1908, Lazursky dedicated himself to the study of methods that resulted in a closer approximation with the individual (Korsakov, 1977). He attempted to structure such investigation by means of scientific parameters, which portrayed the exact condition of psychology in the first decades of the twentieth century, especially because researchers of that time had the need to develop researches and works that valued psychology as Science (Brozek \& Pongratz, 1980; Danziger, 2000; Lourenço \& Campos, 2000).

Educators in Russia started practicing the evaluation proposed by Lazursky and spread it as a characterological method for the construction of personality profiles. They observed children in their homes and school, which provided them with ways to evaluate and intervene in their students' development from the individual's own profiles, a part of their own personality. Thus, the Natural Experimentation method had the fundamental condition for what teachers were searching, as a way to deepen their knowledge about the students and their learning process. The method excelled at the configuration of a setting full of stimuli in which the students could choose the activity they would perform according to their own interests (Campos, 2012).

Lourenço and Campos (2000) described, based on Antipoff's writings, how the educator explained the way the Russian researcher designed the method:

According to Helena Antipoff (1926), Lazursky, knowing the existing methods for personality characterization and their limitations, attempted to improve them. After a number of investigations involving the application of several psychological tests for school-aged children, interviews with their parents and teachers, observations of the children under their natural conditions (at their homes and school) and the comparison between the results obtained by the tests and those obtained by the observation of the children in day-by-day activities at school, Lazursky proposed a third methodology. This new methodology stemmed from the synthesis between the experimentation method and the observation one: the natural experimentation. (p.4)

Lazursky died in 1917 and Antipoff first knew the Natural Experimentation only between 1921 and 1923 when she worked in the triage, referral and reeducation of orphan children. The method was outstanding in Russia, being one of the main works developed in the reference centers for investigating the child's personality (Antipoff, 1992). In the educator's writings, Lazursky arose as a great reference for the study of personality and his method was valued for allowing the exploration of the child's natural manifestations: "We experiment with the natural ways under external conditions. We study the individual by life itself, and the child, by the school teaching objects" (Antipoff et al., 1937, p. 302).

Antipoff believed that the advantages of the Natural Experimentation lay exactly in the possibility of observing the child under natural conditions, resulting in contributions to a character science, which was able to determine among the psychological functions the ones that more significantly characterized the individual differences. The methodical observation promoted by means of the Natural Experimentation provided guidelines for the elaboration of more efficient and economical educative processes in the special pedagogy (Antipoff et al., 1937, p. 302).

The Natural Experimentation application form, used by Antipoff, was composed of ten exercises of a number of 10-12-year olds'day-by-day experience in the school activities. Throughout the process, there were 
continuous notes, with records of the child's behavior and manifestations. According to Antipoff (1926, p. 295), "The analysis is not purely logical and abstract, but also psychological and concrete". The characterological profile building then took place by means of the character traits that such experiments used to reveal.The method took four hours with two 15-minute recreations and with four subjects. Antipoff (1926) said that Lazursky's method for personality observation was regarded an experimental method as the experiment and observation results were assessed both qualitatively and quantitatively, and put into graphics or stars that enabled the representation of the personality characteristics.

\section{Publications About the Practical Application of the Natural Experimentation Between 1930 and 1950}

The Natural Experimentation application context involved institutions created during the New School period in Brazil, as an attempt to solve social and economic problems with education in the country. The New School movement, which started its process at the end of the nineteenth century and got stronger in the 1930's, brought up a new reflection over the pedagogic practices and knowledge through the renewal of the educational system along with the social reform. The traditional teaching, characterized as passive, was no longer the only way to structure the school; the student started having a more active and central place. In order to shape this process, the teaching method would be within sciences and the relation of the student with knowledge (Almeida \& Assis, 2013; Vidal \& Paulilo, 2003).

The Pestalozzi Society of Minas Gerais, founded on November 10, 1932, was one of the institutions created by Antipoff with the help of a group of collaborators. There was the prospect of creating a referential work on special education in Brazil, counting on a team made up by doctors, pedagogues and psychology professionals who were the first psychologist figure in this country (Alvim, 1967; Borges, 2015; Jacó-Vilela, 2011).

One of these publications was, “The Natural Experimentation as a method for studying the personality and character education", published by Antipoff in 1937, which described the use of Lazursky's method at the Pestalozzi Institute within The Pestalozzi Society of Minas Gerais. In this publication, the educator explained that the Pestalozzi Institute was a day school for the exceptional children in Belo Horizonte that had a program with educative activities, which included school subjects and those for special education of mental functions. Mental orthopedics and systematic material organization, by authors, such as Montessori, Vilas Boas and Asen, etc., were used as didactic methods. Mental orthopedics were a method that applied several psychomotor exercises in order to stimulate the cognitive skills, such as attention, memory, perception, etc. (Petersen, 2017). Psychologist Alfred Binet developed this method in 1910, which Antipoff regarded as a systematic training for strengthening the mental functions (Antipoff, 1992; Borges, 2015). There were also manual works and the vocational-technical education focused especially on housework.

Boys between 10 and 18 years old, residents at Afonso de Moraes Child Shelter who spent the day at the Pestalozzi Institute, did the cleaning and earned remunerations according to their work enhancement, included in the bankbooks at the Bank of the Institute. Later, they could spend that money at the little shop of the Institute itself. In order to evaluate the performance and dedication of each boy to the work, they implemented individual charts that they tailored, according to Antipoff, in psychological terms that were understandable for the children. They organized these psychological terms in categories, such as working speed, care with the material, responsibility, initiative, good mood, and so on. These charts also guided 
the teachers and the boys themselves for the understanding of the work, of their capabilities and their character and they worked to distribute the remuneration that was compatible with what they deserved (Antipoff et al., 1937). "... Each typical reaction had a characterological meaning; according to the intensity of the manifestation, the more or less intense degree of the psychological reaction is evaluated" (Antipoff et al., 1937, p. 302).

They made reports based on observations of the modalities and placed them hierarchically from the simplest and easiest ones to the hardest ones to be performed, as follows: 1-Sweeping the sidewalk (cemented); 2-Sweeping the Yard (Earth); 3-Cleaning the shed and the gutters; 4-Cleaning the side and front porches; 5-Cleaning the toilets and sinks; 6-Dusting the furniture; 7-Sweeping the ceilings; 8-Waxing the floors (wooden and tiles). For each manifestation intensity, the values were distributed at rates 1-5 along with their representation for a characterological meaning (1-awful, 2-bad, 3-average, 4-good, 5-excellent) as a reference of the psychological manifestations during the activity. This helped describe the boys' dedication during the activity and defined the technical modalities and their psychological counterparts for the cleaning work performance (Antipoff et al., 1937).

The assessment consisted of checking the boys' profiles during the activities, according to the characterological manifestations of the intellectual, social and moral traits. They took into account ten items: 1-Habits of initiating the work quickly; 2-Method (that is, reasonable sequence of activities); 3-Perseverance during the same job; 4-Care with the material; 5-Power and speed during the job; 6-Initiative; 7-Responsibility; 8-Mood during the job; 9-Skill and care; 10-Leadership of the group. They also rated them 1-5 to describe the progress for six months of work (See Figure 1). They inserted the items and rates into a star graph to represent the average profile per group and per individual (Antipoff et al., 1937) (See Figure 2).

As we can see, Figure 1 shows the evolution (numbers 1-5 according to the intensity) of each boy at the housework chore proposed as an activity, whose evaluation was carried out in two different times (columns 1 and 2). During the activities, they wrote down records focused on the psychological functions and on the character traits that the experiment could bring about, such as moves, feelings, imagination, perception and memory, and thought and will. They built the star-shaped graph (Figure 2) under the criteria chosen for the observation meaning to show both the individual and group evolutions (Antipoff, 1926; Antipoff et al., 1937).

The appropriation of Lazurky's work helped the elaboration of the method in the school environment, through usual school activities, by also taking into account the rates 1-5 to characterize the students' performances, "We experiment with the natural conditions of the external environment. We study the individual through life itself and the child through the objects of the school education" (Antipoff et al., 1937, p. $302)$.

In 1943, Antipoff wrote with the collaboration of Mrs. Yolanda Barbosa an article entitled Material para $o$ estudo da Experimentação Natural no trabalho (Material for the study of Natural Experimentation at work) that was published at PrimeiroEncontro Curso Pró Criança Excepcional (First Pro Exceptional Childhood Meeting Course) in 1996. It described an experiment with the investigation of the personality using Lazursky's method, which took place at the Fazenda do Rosário (Rosario's Farm), an educational institution created in Ibirité/ Minas Gerais with the support of the Pestalozzi Society of Minas Gerais.

The analysis of the job by the Natural Experimentation took place every week, at a meeting every Sunday evening, where each one received a score for their respective job in the cleaning, farm work and care with the vegetable garden,rated from 0 to 5 , in which 0 to 1-awful, 2-bad, 3-average, 4-good, 5-excellent. Thus, the 
evaluation would check the interest in the work and discipline. By means of observing and filling out the charts, the job analysis identified the character changes and personality profiles. The students spent one year and seven months on a "methodic, instant and guided" work, which suggests the acquirement of new habits. Condition that Antipoff thought as the way for the moral education and for work as a trade in the individuals' life (Antipoff \& Barbosa, 1943/1966, p. 35).

Tabela II

Apreciação do trabalho da limpeza sob seu aspecto caracterológico

\begin{tabular}{|c|c|c|c|c|c|c|c|c|c|c|c|c|c|c|c|c|c|c|c|c|c|}
\hline \multirow[t]{2}{*}{ 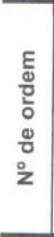 } & & \multicolumn{2}{|c|}{ 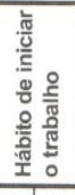 } & \multicolumn{2}{|c|}{$\begin{array}{l}\stackrel{0}{0} \\
\stackrel{0}{\oplus} \\
\Sigma \\
\end{array}$} & \multicolumn{2}{|c|}{ 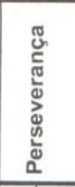 } & \multicolumn{2}{|c|}{ 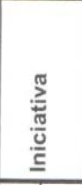 } & \multicolumn{2}{|c|}{$\begin{array}{l}\stackrel{0}{0} \\
\frac{0}{2} \\
\frac{0}{0} \\
\end{array}$} & \multicolumn{2}{|c|}{ 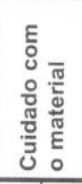 } & \multicolumn{2}{|c|}{ 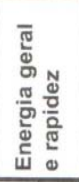 } & \multicolumn{2}{|c|}{ 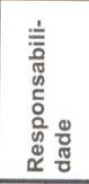 } & \multicolumn{2}{|c|}{ 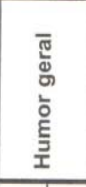 } & \multicolumn{2}{|c|}{ 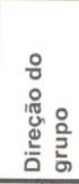 } \\
\hline & & 1 & II & 1 & II & 1 & II & 1 & II & 1 & II & I & II & 1 & ॥ & 1 & II & 1 & ॥ & 1 & II \\
\hline 1 & Antônio Th. & 2 & 3 & 3 & 4 & 3 & 4 & 3 & 4 & 3 & 4 & 3 & 4 & 2 & 3 & 3 & 4 & 1 & 3 & 3 & 4 \\
\hline 2 & Bráulio & 2 & 4 & 2 & 4 & 3 & 4 & 2 & 4 & 3 & 4 & 2 & 3 & 2 & 3 & 2 & 4 & 3 & 4 & & \\
\hline 3 & Boanerges & 3 & 4 & 3 & 4 & 3 & 3 & 2 & 3 & 3 & 4 & 3 & 4 & 2 & 2 & 3 & 4 & 4 & 5 & & \\
\hline 4 & Caio & 3 & 4 & 3 & 4 & 3 & 4 & 3 & 4 & 3 & 4 & 3 & 4 & 3 & 3 & 3 & 4 & 4 & 4 & & \\
\hline 5 & Claudionor & 2 & 5 & 3 & 4 & 3 & 4 & 3 & 4 & 4 & 5 & 3 & 5 & 3 & 4 & 3 & 5 & 4 & 5 & 3 & 4 \\
\hline 6 & Edson & 2 & 3 & 2 & 3 & 2 & 2 & 2 & 2 & 2 & 3 & 2 & 2 & 2 & 3 & 2 & 2 & 3 & 4 & & \\
\hline 7 & Euclydes & 3 & 4 & 3 & 4 & 3 & 4 & 3 & 4 & 3 & 4 & 3 & 4 & 3 & 4 & 4 & 5 & 2 & 4 & & \\
\hline 8 & Geraldo B. & 3 & 4 & 3 & 4 & 3 & 4 & 3 & 5 & 3 & 4 & 3 & 4 & 3 & 4 & 3 & 4 & 3 & 4 & 3 & 4 \\
\hline 9 & Geraldo J. & 3 & 5 & 3 & 5 & 2 & 5 & 2 & 4 & 3 & 4 & 2 & 4 & 3 & 4 & 2 & 3 & 3 & 4 & & \\
\hline 10 & Geraldo C. & 2 & 4 & 2 & 4 & 2 & 3 & 2 & 3 & 3 & 4 & 1 & 3 & 2 & 2 & 1 & 2 & 1 & 3 & & \\
\hline 11 & Jefferson & 3 & 4 & 3 & 4 & 3 & 4 & 3 & 4 & 3 & 4 & 3 & 4 & 3 & 3 & 3 & 4 & 3 & 4 & & \\
\hline 12 & José Carlos & 3 & 4 & 3 & 4 & 2 & 3 & 3 & 4 & 3 & 3 & 3 & 4 & 3 & 3 & 3 & 4 & 2 & 3 & & \\
\hline 13 & José de Paula & 3 & 4 & 3 & 4 & 4 & 4 & 3 & 4 & 3 & 4 & 3 & 3 & 3 & 3 & 3 & 4 & 4 & 4 & & \\
\hline 14 & José Roque & 3 & 3 & 3 & 3 & 3 & 3 & 3 & 3 & 3 & 4 & 3 & 3 & 2 & 3 & 3 & 3 & 3 & 4 & & \\
\hline 15 & José Mathias & 3 & 4 & 3 & 4 & 3 & 4 & 3 & 4 & 3 & 4 & 3 & 4 & 4 & 5 & 3 & 4 & 3 & 3 & & \\
\hline 16 & José Calixto & 3 & 4 & 3 & 5 & 3 & 5 & 3 & 5 & 3 & 5 & 4 & 5 & 3 & 3 & 4 & 5 & 4 & 4 & 4 & 5 \\
\hline 17 & José C. & 2 & 3 & 3 & 4 & 2 & 3 & 2 & 2 & 2 & 3 & 2 & 2 & 3 & 3 & 2 & 2 & 2 & 3 & & \\
\hline 18 & José J. & 3 & 4 & 3 & 4 & 3 & 3 & 3 & 3 & 3 & 4 & 3 & 4 & 2 & 2 & 3 & 4 & 4 & 4 & & \\
\hline 19 & José de L. & 3 & 3 & 3 & 5 & 3 & 5 & 3 & 4 & 4 & 4 & 3 & 4 & 3 & 4 & 3 & 4 & 2 & 3 & 3 & 4 \\
\hline 20 & Joel Carlos & 3 & 4 & 3 & 4 & 3 & 4 & 3 & 4 & 3 & 4 & 3 & 4 & 3 & 4 & 3 & 4 & 2 & 5 & 3 & 3 \\
\hline 21 & Joaquim M. & 2 & 4 & 2 & 4 & 2 & 4 & 2 & 2 & 3 & 4 & 3 & 4 & 3 & 3 & 2 & 4 & 2 & 4 & 4 & 4 \\
\hline 22 & Joāo V. & 3 & 4 & 3 & 4 & 4 & 5 & 3 & 4 & 3 & 5 & 3 & 4 & 3 & 3 & 3 & 4 & 3 & 5 & & \\
\hline 23 & Mano P. & 1 & 3 & 3 & 3 & 3 & 3 & 2 & 3 & 3 & 4 & 1 & 2 & 3 & 4 & 1 & 3 & 1 & 3 & & \\
\hline 24 & Milton N. & 2 & 3 & 3 & 4 & 2 & 3 & 2 & 3 & 3 & 4 & 3 & 4 & 2 & 3 & 2 & 3 & 1 & 3 & & \\
\hline 25 & Olderico & 3 & 4 & 3 & 4 & 3 & 5 & 3 & 3 & 3 & 4 & 3 & 4 & 3 & 3 & 4 & 5 & 4 & 5 & 3 & 4 \\
\hline 26 & Redelvim A. & 2 & 3 & 3 & 3 & 2 & 3 & 2 & 2 & 3 & 4 & 3 & 4 & 3 & 3 & 2 & 2. & 2 & 3 & & \\
\hline 27 & Sebastião S. & 2 & 3 & 3 & 4 & 2 & 3 & 2 & 2 & 3 & 4 & 2 & 3 & 2 & 3 & 2 & 2 & 3 & 4 & & \\
\hline 28 & Silvino & 3 & 4 & 4 & 5 & 4 & 5 & 4 & 5 & 4 & 5 & 4 & 5 & 4 & 5 & 4 & 5 & 4 & 4 & 3 & 4 \\
\hline
\end{tabular}

Obs.: I - nota em março; II - nota em setembro.

Figure 1. Appreciation of the cleaning work in its characterological aspect.

Figure 3 shows the chart containing the distribution of the jobs of cleaning, housekeeping, vegetable gardening, and weeding. For each work category, such as cleaning up the kitchen, sweeping the living room, tidying up the bedroom, cleaning the yard, and so on, the students were assessed according to the intensity of the manifestations, taking into account each one's characterological profile by means of rates 1-5 regarding the job: interest, readiness, endurance, capability, care, and discipline.

In 1945, a job carried out at the Escola de Aperfeiçoamento (Improvement School) under Antipoff's advice was published in the Brazilian Journal of Pedagogic Studies; in it, an observation method based on 
Lazursky's Natural Experimentation was able to create, among student teachers, an experiment of democratic formation (Antipoff, 1945).

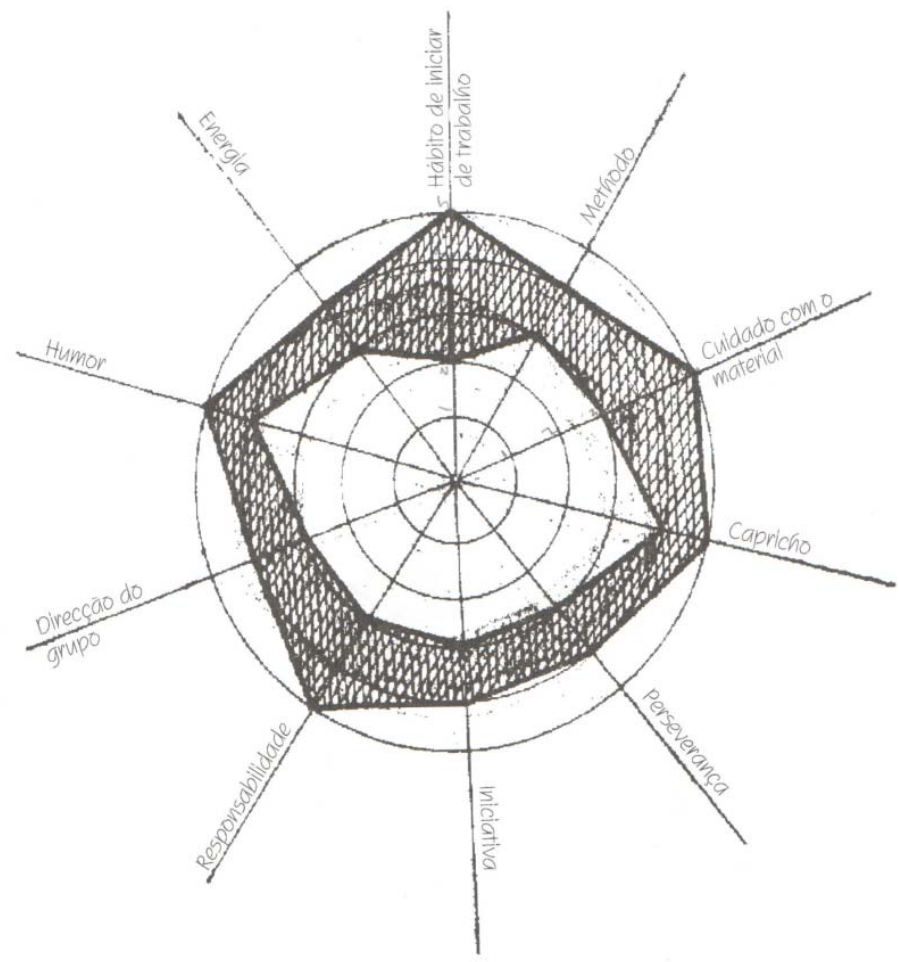

Perfil individual do menor Claudionor progresso realizado num semestre

Figure 2. Star profile on the left for the group of 28 boys and star profile on the right for the individual.

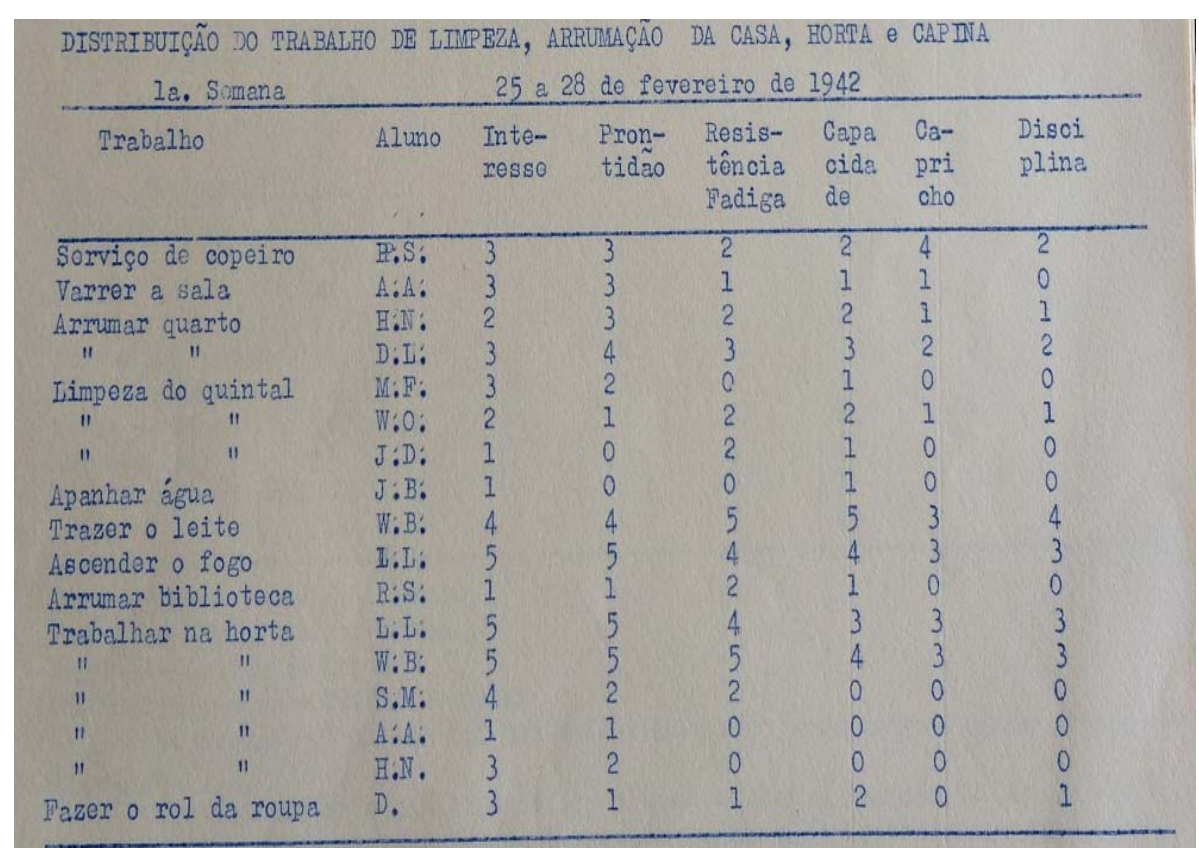

Figure 3. Distribution of the jobs of cleaning, housekeeping, vegetable gardening, and weeding. 
Under those circumstances, the teachers had the chance to carry out several observations, similar to those of Lazursky's Natural Experimentation, during their own work while going through the professional formation. Besides, they filled out characterological profile elaboration charts with their self-judgment, in the case of evaluating their own characters, and with hetero-judgment in case of evaluating their classmates. They noted down arithmetical averages for the partial judgment of each teacher and the group's average in relation with each of the 18 personality traits under judgment.

The 18 personality traits being investigated during the filling out of the charts for both the self-judgment and hetero-judgment were intellectual capability, general knowledge, initiative, self-confidence, organizational skills, punctuality, working capability, devotion, interest in the progress, cooperation, sociability, tact, self-control, loyalty, physical endurance, emotive behavior, trust in others, and consistency of the jobs. According to Antipoff (1945):

Finalizing the presentation of the technique proposed for the observation training and judgment of psychic qualities of intellectual, emotional, social, moral etc. type in people with a close relationship, we shall say that it works, in our viewpoint, as a resource, among many others, for the formation of democratic attitudes. (p. 235)

All the applications of Natural Experimentation described here had as main objective the investigation of the personality in daily jobs at school. Students and teachers benefited from this process as a new model proposed by the New School that prized learning through natural manifestations of behavior. The appropriation of Lazursky's method allowed a closer look at the individuality and at the characterological profiles of each student as a way to help the development of important life skills.

\section{Considerations}

Our study claims that the investigation of the personality was a part of a research field at the schools managed by Antipoff and its biggest focus lay in the observation under a natural condition. Antipoff used the Natural Experimental method in a particular context, mainly in the sense of investigating the individual characteristics, and later, proposing educational interventions.

According to the studied sources, she applied the method to students, but it was also present in the self-knowledge work of the teachers towards a democratic education. An initiative that fit in the New School context and in the new projects that were spread throughout Brazil in the 1930's, especially in the state of Minas Gerais, where the educational process acquired a more individual perspective and with a greater participation of psychology.

It was not only about investigating and setting up personality characterological profiles, but also about building the follow-up of these individuals throughout the development of skills and a greater life functionality of those who were "excluded" from society. The method helped check how much a certain individual had accomplished in relation to their own progress, which allowed adaptations towards a more productive and autonomous life.

\section{Primary Documents}

Antipoff, H., Ottoni, F., \& Duarte, C. (1937). Experimentação natural como método para estudo da personalidade e da educação de caráter. In R. H. F. Campos (org.) (2002), Helena Antipoff: textos escolhidos (pp. 301-318). São Paulo: Casa do Psicólogo; Brasília: Conselho Federal de Psicologia. The original documents 
are from 1937, but the book used in this paper was published in 2002.

Antipoff, H., \& Barbosa, Y. (1943/1966). Material para estudo da Experimentação Natural no trabalho. $1 o$ Encontro Curso Pro Infância do Excepcional. CDPHA (Centro de Documentação e Pesquisa Helena Antipoff), Belo Horizonte.

Antipoff, H. (1945). Dos perfis caracterológico como elemento de educação democrática. In R. H. F. Campos (org.) (2002), Helena Antipoff: textos escolhidos (pp. 227-236). São Paulo: Casa do Psicólogo; Brasília: Conselho Federal de Psicologia. The original documents are from 1945, but the book used in this paper was published in 2002.

Antipoff, H. (2002). Estudo da personalidade pelo método de Lazursky. (R. H. F. Campos, Trans.). São Paulo: Casa do Psicólogo; Brasília: Conselho Federal de Psicologia. (Original work published in 1926: Étude de la personnalité par lá methode Lazoursky. Geneve: L'educateur). The original documents are from 1926, but the book used in this paper was published in 2002.

Antipoff, H. (1992). A Experimentação Natural: método psicológico de A. Lazursky. In Centro de Documentação e Pesquisa Helena Antipoff (org.), Coletânea das Obras Escritas de Helena Antipoff-Psicologia Experimental V. I (pp. 29-41). Belo Horizonte: Imprensa Oficial.

Minas Gerais (Estado). (1937). Decreto no 887, de 30 de junho de 1937 (Publicação No.5, 8). Minas Gerais: Brasil. Programas da Escola de Aperfeiçoamento. Imprensa Oficial, Belo Horizonte.

\section{References}

Alvim, F. C. (1967). Introdução ao estudo da Deficiência Mental (Ologofrenias). Belo Horizonte: Editora Itatiaia.

Antipoff, H. (1926). Étude de la personnalité par lá methode Lazoursky. Geneve: L'educateur.

Antipoff, H. (1945). Dos perfis caracterológico como elemento de educação democrática. In R. H. F. Campos (org.), (2002) Helena Antipoff: textos escolhidos (pp. 227-236). São Paulo: Casa do Psicólogo; Brasília: Conselho Federal de Psicologia.

Antipoff, H. (1992). A Experimentação Natural: Método psicológico de A. Lazursky. In Centro de Documentação e Pesquisa Helena Antipoff (org.), Coletânea das Obras Escritas de Helena Antipoff-Psicologia Experimental V. I (pp. 29-41). Belo Horizonte: Imprensa Oficial.

Antipoff, H., \& Barbosa, Y. (1943/1966). Material para estudo da Experimentação Natural no trabalho. 1o Encontro Curso Pro Infância do Excepcional. CDPHA (Centro de Documentação e Pesquisa Helena Antipoff), Belo Horizonte.

Antipoff, H., Ottoni, F., \& Duarte, C. (1937). Experimentação natural como método para estudo da personalidade e da educação de caráter. In R. H. F. Campos (org.) (2002), Helena Antipoff: textos escolhidos (pp. 301-318). São Paulo: Casa do Psicólogo; Brasília: Conselho Federal de Psicologia.

Borges, A. A. P. (2015). De anormais a excepcionais: Históricas de um conceito e de práticas inovadoras em educação especial. Curitiba: Editora CRV.

Brozek, J., \& Pongratz, L. (1980). Historiography of Modern Psychology. Toronto: C.J. Hogrefe, Inc.

Campos, R. H. F. (org.). (2002). Helena Antipoff: Textos escolhidos. São Paulo: Casa do Psicólogo; Brasília: Conselho Federal de Psicologia.

Campos, R. H. F. (2012). Helena Antipoff: Psicóloga e educadora: uma biografia intelectual. Rio de Janeiro: Fundação Miguel de Cervantes.

Danziger, K. (2000). Making social psychology experimental: A conceptual history, 1920-1970. Journal of the History of the Behavioral Sciences, 36(4), 329-347.

Jacó-vilela, A. M. (org). (2011). Dicionário histórico de instituições de Psicologia no Brasil. Brasília: Conselho Federal de Psicologia; Rio de Janeiro: Imago.

Корсакова, С. С. (1977). Лазурский Александр Федорович: Биография. Журнал Невропатологии и Психиатрии Имени, том 77 вып. 6 [Korsakov, S. S. (1977). Lazurskii Alexander Fedorovich: Biography. Journal of Neuropsychiatry, 77(6)]. Retrieved from http://forpsy.ru/biography/otechestvennye_psikhologi/lazurskiy_aleksandr_fedorovich/ 
Lourenço, E, \& Campos R. H. F. (2000). O método da experimentação natural de Lazursky: Sua aplicação nas propostas educacionais de Helena Antipoff em Minas Gerais (1932-1974). $1^{\circ}$ Congresso Brasileiro de História da Educação. Retrieved from http://www.sbhe.org.br/novo/congressos/cbhe1/anais/049_erika.pdf

Maranhão-filho, P., Maranhão, E. T., \& Engelhardt, E. (2015). Life and death of Vladimir Mikhahaillovich Bekhterev. Arquivos de Neuro-Psiquiatria, 73(11), 968-971.

Petersen, L. M. (2017). Exercitar as funções psíquicas: Ortopedia mental como método de ensino das classes especiais (1930). Revista Brasileira de Educação Especial, 23(1), 127-144.

Rafante, H. C., \& Lopes, R. E. (2006). Educação e trabalho nas instituições para crianças excepcionais mineiras nas décadas de 1930 e 1940. Dissertação de mestrado, Universidade Federal de São Carlos, São Carlos, SP, Brasil.

Vidal, D. G., \& Paulilo, A. L. (2003). Projetos e estratégias de implementação da escola nova na capital do brasil (1922-1935). In A. N. Magaldi, \& J. G. Gondra (Eds.), Educação no Brasil: História, Cultura e Política (pp. 375-398). Bragança Paulista: EDUSP. 